\title{
A Comparative Study Assessing Surgical Outcome of Excision of Giant or Multiple Benign Breast Lesions Using Circumareolar Incision versus Round Block Technique
}

\author{
ASHRAF EL-ZOGHBY, M.D.; HANY R. WAKIM, M.D.; DINA H. AHMED, M.D.; \\ AHMED F. AMER, M.D. and ABDEL-RAHMAN A. ABDEL-AZIZ, M.Sc. \\ The Department of General Surgery, Faculty of Medicine, Ain Shams University
}

\begin{abstract}
Background: Breast disease seriously affects the physical and mental health of women. In recent years, the incidence rates of Benign Breast Tumors (BBTs) and malignant tumors have been rising. The traditional surgical resection method for the various types of BBT leaves obvious scars and affects the appearance of the breast, with the continuous development of the social economy and the gradual improvement of living standards, demands for breast appearance are higher. Surgery should not only cure the breast disease, but it should also avoid damage to the functions and appearance of the breasts. Benign breast lesions, especially when multiple or giant, constitute a difficulty in obtaining complete wide excision with minimal breast deformity and minimal small scars in addition to the high risk of recurrence. In cases of benign breast lesions, bad cosmetic results are unacceptable neither by the patients nor by the surgeons.
\end{abstract}

Aim of Study: The aim of the study is to compare between post-operative outcome of surgical excision of giant or multiple benign breast lesions (giant fibro adenomas or phylloids tumors) through a circum-areolar incision versus round block technique as regard cosmetic \& oncological outcome \& patient satisfaction.

Patients and Methods: It was a prospective randomized study that included 20 patients aiming to compare between post-operative outcome of surgical excision of giant or multiple benign breast lesions (giant fibro adenomas or phylloids tumors) through a circum-areolar incision versus round block technique as regard cosmetic \& oncological outcome \& patient satisfaction. This study was conducted at Ain-Shams University Hospitals. Approval of the Ethical Committee and written informed consent from all participants was obtained. Circumareolar incisions and Round block techniques were proposed for patients in whom breast conservative treatment is possible on oncologic grounds but where a standard resection without reconstruction would lead to a poor cosmetic outcome. Study period: March 2020 to October 2020.

Results: It was found that there is a rapid progress in the development of diagnostic methods and interventional methods of diagnosis. This increased the accuracy of these methods

Correspondence to: Dr. Ashraf El-Zoghby, The Department of General Surgery, Faculty of Medicine, Ain Shams University and their ability to differentiate benign from malignant tumors. Also the round block techniques proved to have a better outcome than the circumareolar technique in all the previous mentioned criteria.

Conclusion: The application of oncoplastic surgery to benign breast disease is a new revolution in the surgical management of cases and should be the standard of care for selected cases.

Key Words: Assessing surgical outcome-Giant-Multiple benign breast lesions - Circumareolar incision Round block technique.

\section{Introduction}

BREAST lump is a major health concern amongst women at any age as it invokes fear of malignancy. Increased awareness has resulted in patients seeking early surgical consultation. Early confirmation of diagnosis and treatment is necessary as the patient is under tremendous psychological stress [1].

In recent years, the incidence rates of Benign Breast Tumors (BBTs) and malignant tumors have been rising. BBTs are much more common than malignant breast cancer, accounting for $>90 \%$ of referrals to secondary care. BBTs include fibro adenoma, intraductal papilloma, lipomyoma, phylloids, complicated cysts and others [2].

Triple assessment of lump by clinical examination, Ultrasonography (USG) and Fine-Needle Aspiration Cytology (FNAC) is a very useful diagnostic tool to evaluate breast lumps. Among different benign breast conditions, Fibro Adenomas (FAs) are the most common benign tumors occurring in women younger than 35 years. Conservative therapy has been tried for FAs, but it requires long term periodic monitoring ultimately causing anxiety and discomfort. Hence, only surgical resection is curative [1]. 
The traditional surgical resection method for the various types of BBT leaves obvious scars and affects the appearance of the breast. With the continuous development of the social economy and the gradual improvement of living standards, demands for breast appearance are higher. Surgery should not only cure the breast disease, but it should also avoid damage to the functions and appearance of the breasts [1].

In some instances multiple tumors in multiple quadrants can't be removed through a single conventional incision. Likewise, giant tumors having large tumor breast ratio be excised by traditional incisions without leaving unacceptable scars. In addition, the traditional incisions do not allow for a wide field of action and safe complete removal [1].

Also, Benign breast lesions, especially when multiple or giant, constitutes a difficulty in obtaining complete wide excision with minimal breast deformity and minimal small scars in addition to the high risk of recurrence. In cases of benign breast lesions, bad cosmetic results are unacceptable neither by the patients nor by the surgeons [2].

Therefore the choice of method for BBT resection should aim to minimize obvious scarring and maintain the overall appearance of the breasts. Several incisions were tried including circumareolar, round block technique \& infra-mammary incision; this allows good treatment of the BBT and minimal local periareolar scarring. When minimal external scarring and changes to the overall appearance of the breast are requested by the patients [3].

\section{Aim of the work:}

The aim of the study is to compare between postoperative outcome of surgical excision of giant or multiple benign breast lesions (giant fibro adenomas or phylloids tumors) through a circumareolar incision versus Round block technique as regard cosmetic \& oncological outcome \& patient satisfaction.

\section{Patients and Methods}

\section{Type of the study:}

It was a prospective randomized study that included 20 patients aiming to compare between post-operative outcome of surgical excision of giant or multiple benign breast lesions (giant fibro adenomas or phylloids tumors) through a circumareolar incision versus Round block technique as regard cosmetic $\&$ oncological outcome $\&$ patient satisfaction.

\section{Study settings:}

This study was conducted at Ain-Shams University Hospitals. Approval of the Ethical Committee and written informed consent from all participants was obtained. Circum-areolar incisions and Round block techniques were proposed for patients in whom breast conservative treatment is possible on oncologic grounds but where a standard resection without reconstruction would lead to a poor cosmetic outcome. Diagnosis and staging examinations were carried out according to the standard protocol being conducted at Ain Shams University Hospitals. In-patient post-operative recovery time ranged from twenty four hours to a maximum of two days. All patients were discharged with a set of instruction and follow-up schedule. Our patients were all followed-up for both oncologic and cosmetic grading and after conventional pathological evaluation.

Study period:

March 2020 to October 2020.

\section{Study population:}

Patients undergoing surgical excision of benign breast tumors who were presented at Ain Shams University Hospitals. Patient selection was achieved through a number of inclusion and exclusion criteria.

\section{Inclusion criteria:}

- Patients with age ranging from (20-60) years old.

- Benign breast lesions whether it was giant solitary or multiple.

- Large benign breast lesions including fibro adenomas, phylloids tumors, complicated cysts.

\section{Exclusion criteria:}

- Malignant lesions.

- Mass in the axillary tail or peripherally located where circum areolar incision is not applicable or with size less than $4 \mathrm{~cm}$ in diameter.

- Patients not convinced with proposed procedure after adequate explanation and patients refusing.

- Patients with contraindication to breast conserving surgery were carefully excluded from the study.

All patients were submitted to history taking including full personal history, compliant, analysis of their disease along with thorough medical and family history with its relevance to the condition, complete clinical examination in the outpatient clinic. 
Pre-operative investigation was performed that included laboratory tests including blood tests as complete blood count, liver profile, kidney profile, coagulation profile, blood sugar, radiological examination: Including bilateral digital mammography in at least two views (Cranio-caudal and mediolateral oblique), CT Chest as a part of covid 19 screening protocol, ECG and echocardiography were performed upon requested by the anaesthiologist when indicated, tissue biopsy using true cut needle core biopsy in any patients that had suspicious radiography.

\section{Patient counseling and consent:}

After admission and completion of history and examination each patient received a detailed explanation of her condition regarding the disease itself, the type of surgery and expected recurrence rates, operative details of the selected technique for each patient was explained using pictures of similar cases to help visualization of the outcome, risks and benefits of the suggested procedure along with it's possible intra and post-operative possible complications were also clearly stated and explained individually for each procedure. Which included wound infection, fat necrosis, NAC sloughing, asymmetry or failure of adequate cosmetic outcome and incidence of local recurrence.

\section{Pre-operative marking:}

Mark up and design of planned incision were done on the morning of the surgery in the holding area of the operating theatre in the presence of the breast nurse and the surgical team. Measurements were taken and kept with the patient standing in an upright position prior to receiving pre-anesthetic drugs. Drawings were made using water proof skin markers. Pre-operative drawings, outer and inner incision lines marked with arrows, area in between to be de-epithelialzed, 1 to $2 \mathrm{~cm}$ distance between inner and outer incision line depending on tumor size, location and nipple position. The more breast volume to be excised, the more ptosis to be corrected, the larger the distance between inner and outer incision line.

Pre-operative drawing for round block technique:

A pre-operation photography session is made now again for documenting the breast measurements and incision sites to help auditing the final cosmetic outcome according to each patient and each breast size.

\section{Operating room set up and surgical equipment:}

Surgery was performed in the operating rooms of the Ain Shams University Hospitals.

\section{Surgical technique:}

The patient is placed in the supine position with the arms abducted for axillary access, with the possibility to seat the patient on the operative table to control the symmetry.

Two techniques were used which are round block technique, circum areolar incision:

I- Round block technique.

II- Periareolar technique.

\section{Assessment of cosmetic outcome:}

The cosmetic results were evaluated by the general surgeon, the plastic surgeon and the patients. The patient's assessment was similar to the surgeon's assessment regarding is the technique of choice acceptable or not. Cosmetic outcome was evaluated during the early post-operative period and on follow-up. Evaluation was done by means of scoring system, graded from one to five, one indicating poor results and five indicating excellent results.

Quality of life domains: Psychosocial wellbeing, sexual well-being, physical well-being chest and upper body.

Satisfaction domains: Satisfaction with breasts, satisfaction with nipples, satisfaction with outcome, satisfaction with care.

\section{Results}

Table (1): Mean age of the study for each group which was non significant.

\begin{tabular}{|c|c|c|c|c|c|}
\hline \multirow[b]{2}{*}{ Age } & \multicolumn{2}{|c|}{ Technique } & \multirow[b]{2}{*}{$\begin{array}{c}\text { Test } \\
\text { value }\end{array}$} & \multirow{2}{*}{$\begin{array}{c}p- \\
\text { value }\end{array}$} & \multirow[b]{2}{*}{ Sig. } \\
\hline & $\begin{array}{c}\text { Group (A) } \\
\text { No. }=10\end{array}$ & $\begin{array}{c}\text { Group (B) } \\
\text { No. }=10\end{array}$ & & & \\
\hline Mean \pm SD & $37.00 \pm 11.25$ & $41.40 \pm 8.30$ & $-0.995 \bullet$ & 0.333 & NS \\
\hline Range & $20-49$ & $29-54$ & & & \\
\hline \multicolumn{3}{|c|}{$\begin{array}{l}p \text {-value }>0.05: \text { Non significant }(\mathrm{NS}) . \\
p \text {-value }<0.05: \text { Significant }(\mathrm{S}) . \\
p \text {-value }<0.01 \text { : Highly significant }(\mathrm{HS}) .\end{array}$} & \multicolumn{3}{|c|}{$\begin{array}{l}* \text { : Chi-square test. } \\
\bullet: \text { Independent } t \text {-test. }\end{array}$} \\
\hline
\end{tabular}

The age of the patients varied from 20 and 60 years old. The mean age for our study was 39.2 for the both groups combined together.

Prior to the operation the seven patients were consulted to internal medicine and Cardiology Departments respectively, and their recommendations were fulfilled.

On pre-operative patient preparation, full history taking and full labs are done, 7 patients among the 20 patients were found to have medical comorbidities. 3 patients have diabetes mellitus, 2 patients have hypertension, and 1 patient has rhematic heart disease and 1 patient has ischemic heart disease. 
Table (2): Number and percent of medical co-morbidities which wasnot significant.

\begin{tabular}{lccccc}
\hline \multirow{2}{*}{$\begin{array}{l}\text { Medical } \\
\text { Co-morbidities }\end{array}$} & $\begin{array}{c}\text { Group (A) } \\
\text { No.=10 }\end{array}$ & $\begin{array}{c}\text { Group (B) } \\
\text { No.=10 }\end{array}$ & $\begin{array}{c}\text { Test } \\
\text { value }\end{array}$ & $\begin{array}{c}p \text { - } \\
\text { value }\end{array}$ & Sig. \\
\cline { 2 - 5 } No & $6(60.0 \%)$ & $7(70.0 \%)$ & $2.410 *$ & 0.661 & NS \\
DM & $2(20.0 \%)$ & $1(10.0 \%)$ & & & \\
HTN & $1(10.0 \%)$ & $1(10.0 \%)$ & & \\
Rhematic. Fever & $1(10.0 \%)$ & $0(0.0 \%)$ & & \\
ISHD, HTN & $0(0.0 \%)$ & $1(10.0 \%)$ & & \\
\hline$p$-value $>0.05:$ Non significant (NS). & \multirow{2}{*}{$*$ : Chi-square test. } \\
$p$-value <0.05: Significant (S). & & & \\
$p$-value <0.01: Highly significant (HS). & &
\end{tabular}

Table (3): Tumor side and number in the study which were not significant.

\begin{tabular}{|c|c|c|c|c|c|}
\hline & \multicolumn{2}{|c|}{ Technique } & \multirow{2}{*}{$\begin{array}{c}\text { Test } \\
\text { value** }\end{array}$} & \multirow{2}{*}{$\begin{array}{c}p^{-} \\
\text {value }\end{array}$} & \multirow{2}{*}{ Sig. } \\
\hline & $\begin{array}{c}\text { Group (A) } \\
\text { No. }=10\end{array}$ & $\begin{array}{c}\text { Group (B) } \\
\text { No. }=10\end{array}$ & & & \\
\hline \multicolumn{6}{|c|}{ Side of the tumor: } \\
\hline Left & $7(70.0 \%)$ & $3(30.0 \%)$ & $3.200 *$ & 0.074 & NS \\
\hline Right & $3(30.0 \%)$ & $7(70.0 \%)$ & & & \\
\hline \multicolumn{6}{|c|}{ No. of the tumors: } \\
\hline 1 & $7(70.0 \%)$ & $7(70.0 \%)$ & $3.000 *$ & 0.223 & NS \\
\hline 2 & $3(30.0 \%)$ & $1(10.0 \%)$ & & & \\
\hline 3 & $0(0.0 \%)$ & $2(20.0 \%)$ & & & \\
\hline $\begin{array}{l}p \text {-value } \\
p \text {-value } \\
p \text {-value }\end{array}$ & $\begin{array}{l}\text { ignificant } \\
\text { icant }(\mathrm{S}) \text {. }\end{array}$ & $\begin{array}{l}\text { S). } \\
\text { (HS). }\end{array}$ & *: Chi & juare & \\
\hline
\end{tabular}

The tumor number and sides was evaluated by ultrasound done for all cases before operation as an integral step of the triple assessment. The tumor number is evaluated by the largest number of the tumor mass. The least tumor number was 1 tumor; the most was 3 .

Table (4): BIRADS classification for each group in the study which was non significant.

\begin{tabular}{llcccc}
\hline \multirow{2}{*}{$\begin{array}{l}\text { BIRADS } \\
\text { classification }\end{array}$} & $\begin{array}{c}\text { Group (A) } \\
\text { No.=10 }\end{array}$ & $\begin{array}{c}\text { Group (B) } \\
\text { No.=10 }\end{array}$ & $\begin{array}{c}\text { Test } \\
\text { value* }\end{array}$ & $\begin{array}{c}p \text { - } \\
\text { value }\end{array}$ & Sig. \\
\cline { 2 - 5 } & $4(40.0 \%)$ & $3(30.0 \%)$ & $1.486^{*}$ & 0.686 & NS \\
3 & $4(40.0 \%)$ & $3(30.0 \%)$ & & & \\
4 & $0(0.0 \%)$ & $1(10.0 \%)$ & & & \\
$4 \mathrm{a}$ & $2(20.0 \%)$ & $3(30.0 \%)$ & & & \\
\hline
\end{tabular}

$p$-value $>0.05$ : Non significant (NS).

*: Chi-square test.

$p$-value <0.05: Significant $(\mathrm{S})$

$p$-value <0.01: Highly significant (HS).

The tumor BIRADS classification was evaluated by ultrasound or mammography done for cases before operation as an integral step of the triple assessment. The BIRADS classification is graded from 0 to 6 where the grade 0 means in complete study, grade1 means no abnormal findings, grade 2 benign lesion, grade 3 means mostly benign, grade 4 means probably suspicious lesion needs biopsy and grade $5 \& 6$ high risk for malignancy, our study falls in the area from grade 2 to $4 \mathrm{a}$ as follows, seven patients were BIRADS 2, where four of them were in group (A) and three in group (B), seven patients were BIRADS 3 also where four of them were in group (A) and three in group (B), six patients were BIRADS 4 where two of them were in group (A) and the other four in group (B).

Table (5): Biopsy taking chart for each group in the study which was non significant.

\begin{tabular}{|c|c|c|c|c|c|}
\hline \multirow{2}{*}{ Biopsy } & \multicolumn{2}{|c|}{ Technique } & \multirow{2}{*}{$\begin{array}{c}\text { Test } \\
\text { value }\end{array}$} & \multirow{2}{*}{$\begin{array}{c}p- \\
\text { value }\end{array}$} & \multirow{2}{*}{ Sig. } \\
\hline & $\begin{array}{c}\text { Group (A) } \\
\text { No. }=10\end{array}$ & $\begin{array}{c}\text { Group (B) } \\
\text { No. }=10\end{array}$ & & & \\
\hline Tru Cut & $2(20.0 \%)$ & $4(40.0 \%)$ & $0.952 *$ & 0.329 & NS \\
\hline Exic biopsy & $8(80.0 \%)$ & $6(60.0 \%)$ & & & \\
\hline
\end{tabular}

$p$-value $>0.05$ : Non significant (NS). $p$-value $<0.05$ : Significant (S) $p$-value <0.01: Highly significant (HS). $\quad *$ : Chi-square test.

The tumor BIRADS classification was evaluated by ultrasound or mammography done for cases before operation as an integral step of the triple assessment, for tumors with suspicious birads score biopsy taking was done acc. To the recommendations, in our study the tru-cut or the excisional biopsy were the methods used as follows: Six patients had 4a Birads score so tru cut biopsy were taken pre-operative to ensure the benign nature of the lesions, where the other fourtheen lesions needed excisional biopsy.

Table (6): Mean operation time for our study.

\begin{tabular}{llllll}
\hline \multirow{2}{*}{$\begin{array}{l}\text { Operation } \\
\text { time (h) }\end{array}$} & $\begin{array}{l}\text { Group (A) } \\
\text { No.=10s }\end{array}$ & $\begin{array}{c}\text { Group (B) } \\
\text { No.=10 }\end{array}$ & $\begin{array}{c}\text { Test } \\
\text { value }\end{array}$ & $\begin{array}{c}p- \\
\text { value }\end{array}$ & Sig. \\
\cline { 2 - 5 } & $\begin{array}{l}1.17 \pm 0.30 \\
\text { Mean } \pm \text { SD }\end{array}$ & $1.45 \pm 0.37$ & 1.874 & 0.077 & NS \\
Range & $1-2$ & $0.67-1.5$ & & & \\
\hline
\end{tabular}

$p$-value $>0.05$ : Non significant (NS). $p$-value $<0.05$ : Significant (S) $p$-value $<0.01$ : Highly significant (HS). $\quad$ : Independent $t$-test.

Our mean operation time was 78 minutes (1 hour and 18 minutes), the fastest procedure finished in 60 minutes, longest took 120 minutes, where it shows that the round block technique took longer time where the mean of operations in group (A) was 1.45 , while in group (B) was 1.17.

Table (7): Mean operation blood loss for our study which was insignificant.

\begin{tabular}{|c|c|c|c|c|c|}
\hline \multirow{2}{*}{$\begin{array}{l}\text { Blood } \\
\text { loss }(\mathrm{ml})\end{array}$} & \multicolumn{2}{|c|}{ Technique } & \multirow{2}{*}{$\begin{array}{c}\text { Test } \\
\text { value• }\end{array}$} & \multirow{2}{*}{$\begin{array}{c}p- \\
\text { value }\end{array}$} & \multirow{2}{*}{ Sig. } \\
\hline & $\begin{array}{c}\text { Group (A) } \\
\text { No. }=10\end{array}$ & $\begin{array}{c}\text { Group (B) } \\
\text { No. }=10\end{array}$ & & & \\
\hline Mean $\pm \mathrm{SD}$ & $105.00 \pm 36.89$ & 100.0033 .33 & 0.318 & 0.754 & NS \\
\hline Range & $50-150$ & $50-150$ & & & \\
\hline
\end{tabular}


No patient required blood transfusion neither intra or post-operative. Our mean blood loss volume (ml) was $100 \mathrm{ml}$ blood, the smallest value in the procedure was $50 \mathrm{ml}$, while the largest was $150 \mathrm{ml}$. All 20 patients have had a drain left inside the wound with one limb, that drain the breast wound exiting from lateral side of IMF. The amount of blood lost in the $1{ }^{\mathrm{st}} 24$ hours was estimated by the amount of blood in the drain in the 1 st day postoperative. The mean amount of blood collected in the drain in the 1 st day was $85 \mathrm{ml}$. The maximum amount in the drain was $150 \mathrm{ml}$ while the minimum amount was $50 \mathrm{ml}$.

Table (8): Mean 1 st day post-operative drain amount for the study which was insignificant.

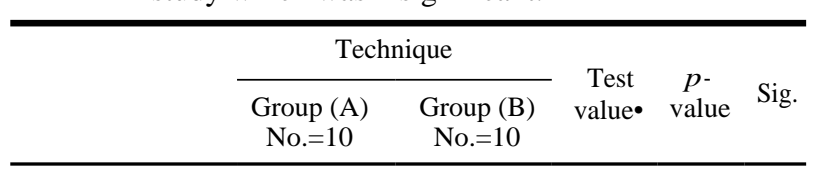

Drainage volume

$(m l)$ :

$\begin{array}{llllll}\text { Mean } \pm \text { SD } & 90.00 \pm 44.41 & 80.00 \pm 22.97 & 0.632 & 0.535 & \text { NS } \\ \text { Range } & 50-150 & 50-100 & & & \end{array}$

Drainage days

removal:

Mean \pm SD $\quad 1.40 \pm 0.52 \quad 1.40 \pm 0.52 \quad 0.000 \quad 1.000 \quad$ NS

Range

$1-2 \quad 1-2$

$p$-value $>0.05$ : Non significant (NS).

$p$-value $<0.05$ : Significant $(\mathrm{S})$.

$p$-value $<0.01$ : Highly significant (HS).

$\bullet:$ Independent $t$-test.

Patients were given a follow-up schedule upon discharge from the hospital as the following in the form of 3 visits in the first week for dressing and monitoring the drains if still present and any complications. The following two weeks every four days until removal of the stitches. During the follow-up period complications occurred only in 5 cases, in the form of 3 cases of seroma formation one of them has also partial nipple necrosis and 2 cases of nipple parathesia.

None of them have had any other problem. Neither the seroma formation hindered neither wound healing nor compromised final cosmetic outcome.

In our study 3 patients had seroma formed, one was with the round block technique and the other two was the circum-areolar technique,we havenot encountererd any patients that developed infection, hematoma, wound dehiscence or ulcer formation, we had two patients with nipple parathesia one was in group (A) and the other in group (B), lastly we had a patient with partial nipple necrosis in group (B).
Table (9): This table shows number and percent of complications among patient population with each technique.

\begin{tabular}{|c|c|c|c|c|c|c|}
\hline & & Tech & nique & & & \\
\hline & Gro & up (A) & Grot & up (B) & Iest & $\begin{array}{c}p- \\
-\end{array}$ \\
\hline & No. & $\%$ & No. & $\%$ & & \\
\hline Seroma & & & & & & \\
\hline No & 9 & 90.0 & 8 & 80.0 & 0.392 & $0.531 \mathrm{NS}$ \\
\hline Yes & 1 & 10.0 & 2 & 20.0 & & \\
\hline Develop & & & & & & \\
\hline No & 10 & 100.0 & 10 & 100.0 & NA & NA NA \\
\hline Yes & 0 & 0.0 & 0 & 0.0 & & \\
\hline Develor & & & & & & \\
\hline No & 10 & 100.0 & 10 & 100.0 & NA & NA NA \\
\hline Yes & 0 & 0.0 & 0 & 0.0 & & \\
\hline Wound & & & & & & \\
\hline No & 10 & 100.0 & 10 & 100.0 & NA & NA NA \\
\hline Partial & & & & & & \\
\hline No & 10 & 10.0 & 9 & 90.0 & 1.053 & $0.305 \mathrm{NS}$ \\
\hline Yes & 0 & 0.0 & 1 & 10.0 & & \\
\hline Nipple & & & & & & \\
\hline No & 9 & 90.0 & 9 & 90.0 & $0.000^{*}$ & $1.000 \mathrm{NS}$ \\
\hline Yes & 1 & 10.0 & 1 & 10.0 & & \\
\hline
\end{tabular}

$p$-value $>0.05$ : Non significant (NS). $p$-value $<0.05$ : Significant (S). $p$-value $<0.01$ : Highly significant (HS). $\quad *$ : Chi-square test.

\section{I- Cosmetic outcome:}

Cosmetic outcome was estimated using a scoring system which was made up from the three independent grading parties (surgeon, patient and MDT of the breast) based on the level of satisfaction to give an overall score for cosmetic outcome.

The cosmetic outcome score was based on multiple items that made up a check list to be evaluated by our team and the MDT of the breast for every single case, this check list: The overall shape of the breast, the symmetry of both breasts, the site and direction of the nipple, the volume of the breast and the skin incision shape.

These elements was discussed for every single case and analyzed to give a scoring system graded from 1 to 5 as the following:

Table (10): Post-operative cosmetic scoring system.

\begin{tabular}{ll}
\hline 5 & Excellent \\
4 & Very good \\
3 & Good \\
2 & Fair \\
1 & Poor \\
0 & Ugly \\
\hline
\end{tabular}

The overall mean score of our study was 4.23 which fall between very good and excellent.

Table (11): Mean cosmetic outcome for our study.

\begin{tabular}{ccccc}
\hline & Mean & 上SD & \multicolumn{2}{c}{ Minimum Maximum } \\
\hline Cosmetic outcome & 4.23 & .86 & 2.00 & 5.00 \\
\hline
\end{tabular}


The following is the number of cases for each grade of the scoring system for the whole study.

Table (12): Number of cases for every score of cosmetic outcome.

\begin{tabular}{lll}
\hline Cosmetic outcome & No. & $\%$ \\
\hline Score 5 & 14 & 70 \\
Score 4 & 4 & 20 \\
Score 3 & 1 & 5 \\
Score 2 & 1 & 5 \\
Score 1 & 0 & 0 \\
Score 0 & 0 & 0 \\
\hline
\end{tabular}

Round block mammoplasty:

Table (13): Mean cosmetic outcome for round block mammoplasty procedure.

\begin{tabular}{lccccccc}
\hline Score & Excellent & $\begin{array}{c}\text { Very } \\
\text { good }\end{array}$ & Good Fair Poor & Ugly & $\begin{array}{c}\text { Mean } \\
\text { score }\end{array}$ \\
\hline Number of cases & 9 & 1 & 0 & 0 & 0 & 0 & 5 \\
\hline
\end{tabular}

Circum-areolar mammoplasty:

Table (14): Mean cosmetic outcome for circum-areolar mammoplasty procedure.

\begin{tabular}{lcccccccc}
\hline Score & Excellent & $\begin{array}{c}\text { Very } \\
\text { good }\end{array}$ & Good & Fair & Poor & Ugly & $\begin{array}{l}\text { Mean } \\
\text { score }\end{array}$ \\
\hline Number of cases & 5 & 3 & 1 & 1 & 0 & 0 & 4.75
\end{tabular}

Round block mammo-plasty had the highest mean cosmetic outcome score 4.75 which approaches the excellent score. The wound being obscured around the NAC at the transitional zone between NAC and skin played an integral role in improving cosmetic outcome, patient satisfaction and acceptance in both early post-operative period and late follow-up period. The final cosmetic outcome is usually accepted. In our study the mean cosmetic outcome for inferior pedicle mammoplasty was 4.25 which fall between excellent and very good.

Table (15): Mean score for satisfaction with breasts for our study.

\begin{tabular}{lcccc}
\hline & Mean & \pm SD & Highest & Lowest \\
\hline Satisfaction with breasts & 91.72 & 15.23 & 100 & 59 \\
\hline
\end{tabular}

The highest score was 100 while the lowest score was 59. The mean score was 91.72. The highest scores were for the cases of round block mammoplasty, followed by cases of circum-areolar mammoplasty.

Table (16): Mean score for satisfaction with nipples for our study.

\begin{tabular}{lcccc}
\hline & Mean & 士SD & \multicolumn{2}{c}{ Highest Lowest } \\
\hline Satisfaction with nipples & 19.13 & 1.75 & 20 & 14 \\
\hline
\end{tabular}

Table (17): Mean score for satisfaction with outcome for our study.

\begin{tabular}{lcccc}
\hline & Mean & 上SD & \multicolumn{2}{c}{ Highest Lowest } \\
\hline Satisfaction with outcome & 91.72 & 15.23 & 100 & 59 \\
\hline
\end{tabular}

The highest score was 100 while the lowest score was 59. The mean score was 91.72. The highest scores were for the cases of round block mammoplasty, followed by cases of circum-areolar mammoplasty.

Table (18): Mean score for psychosocial well-being for our study.

\begin{tabular}{ccccc}
\hline & Mean & \pm SD & \multicolumn{2}{c}{ Highest Lowest } \\
\hline Psychosocial well-being & 92.6 & 11.71 & 100 & 66 \\
\hline
\end{tabular}

Table (19): Mean score for sexual well-being for our study.

\begin{tabular}{lcccc}
\hline & Mean & \pm SD & Highest & Lowest \\
\hline Sexual well-being & 91.76 & 13.46 & 100 & 65 \\
\hline
\end{tabular}

The highest score was 100 while the lowest score was 65 . The mean score was 91.76. The highest scores were for the cases of round block mammoplasty, followed by cases of circum-areolar mammoplasty.
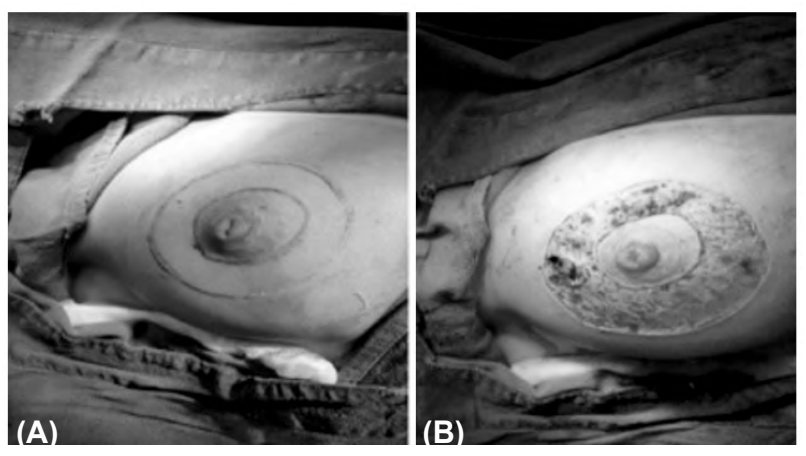

Fig. (1): Round block technique (A) Pre-operative marking (B) De-epithelialization between inner and outer circules.

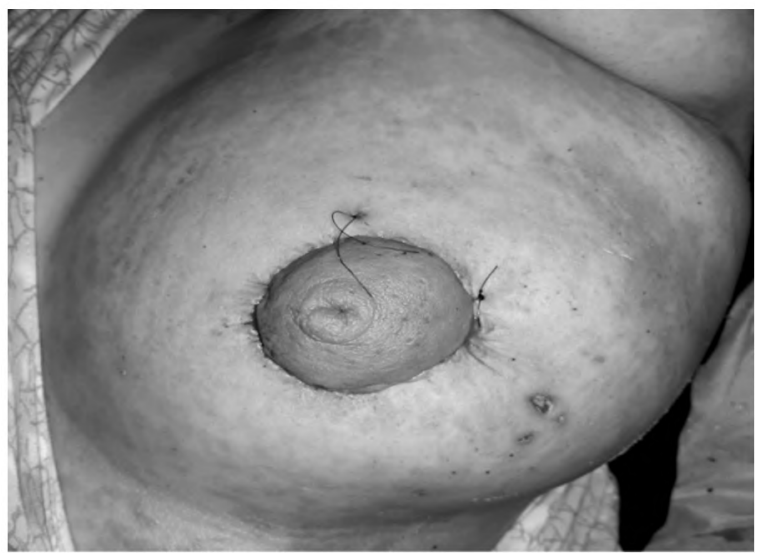

Fig. (2): 1 st post-operative after the operation of round block technique excision of benign breast lesion. 


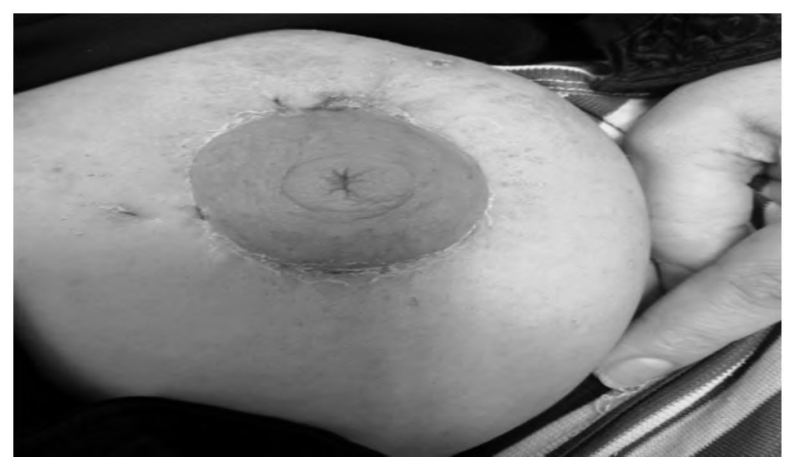

Fig. (3): 3 weeks later after the operation of round block technique excision of benign breast lesion.

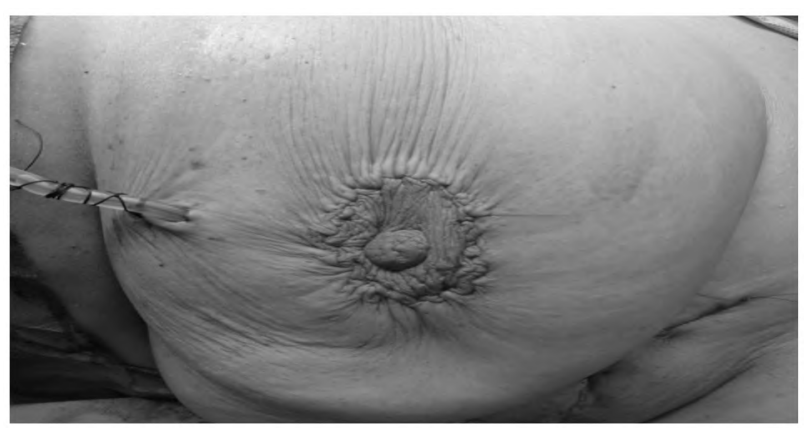

Fig. (4): Post-operative picture of round block technique closure with drain inserted.

\section{Discussion}

A breast lump is a major health concern amongst women at any age as it invokes fear of malignancy. Increased awareness has resulted in patients seeking early surgical consultation. Early confirmation of diagnosis and treatment is necessary as the patient is under tremendous psychological stress [1]

In recent years, the incidence rates of Benign Breast Tumors (BBTs) and malignant tumors have been rising. BBTs are much more common than malignant breast cancer, accounting for $>90 \%$ of referrals to secondary care. BBTs include fibro adenoma, intraductal papilloma, lipomyoma, phylloids, complicated cysts and others [2].

Much attention is paid to the cosmetic outcome in cases with breast cancer and a greater attention should be paid to this outcome in patients with benign breast conditions especially cases in which surgical removal can cause breast deformity or multiple or unacceptable scars [4].

Women especially the young are not willing to accept deformity or ugly scars when they have benign breast lesions. So oncoplastic breast surgery techniques have found good solutions for a better cosmetic outcome than conventional techniques especially in benign lesions especially, the giant and the multiple ones [5].
This article describes novel oncoplastic and therapeutic techniques for the surgical management of giant and multiple benign breast lesions using either the round block technique or the circumareolar technique.

Our results were satisfactory from all aspects regarding the choice of the cases, the technique, the oncological and the cosmetic outcome. Most of the giant and multiple lesions occur in adolescent and young females.

The majority of these masses are benign even if they cause rapid enlargement, and the most common cause of unilateral enlargement is a mass lesion. Furthermore, they can be surgically removed without damaging benign breast tissues.

In cases of giant tumors, the enlargement is due to the volume of the mass itself and not due to the enlargement and hypertrophy of the breast tissues. Removing them through a conventional incision could be very difficult or impossible and will eventually lead to redundant skin, an unacceptable scar, pendulous asymmetric breasts and deformed breast contour and more important recurrence in many instances due to presence of the tumor at the surgical margins of resection, as conventional incisions usually give a narrow field of action for such lesions [6].

The principal in treating these patients lies in balancing an adequate excision and cosmetic outcome, as these giant tumors are usually large by the time they are diagnosed. Round block techniques allow for wide excision and correction of the breast contour. Through this technique and after tumor removal, it is easy to excise the redundant skin only and not of the normal breast tissue except if wide local excision is required not only lumpectomy.

An important technical point, even if you are performing lumpectomy only through conventional incisions and narrow field, it is very difficult to achieve a complete safe excision with an intact capsule as this might lead to presence of the lesion at the surgical margins of resection with a higher incidence of recurrence. In the literature, the most commonly reported approaches used are excision and mastopexy, periareolar and inframammary (Gaillard-Thomas), and most authors recommended mastectomy for recurrent cases. The inframammary and periareolar approaches, which were used in most of the other cases reported in the literature, can allow for removal, but provides a narrow field of action, limits the correction of additional deformities as excessive skin and breast contour [7] 
For such tumors, the advantages over the traditional approach of excision are not only cosmetic but also therapeutic as it allows wider excision for cases like phyllodes tumor and provides good accessibility for removing multiple scattered tumors [5].

Wider excision for cases like phyllodes tumors decreases the incidence of recurrence. In cases of phyllodes tumors, the usual treatment in most series is wide local excision or mastectomy, incomplete excision is accompanied by the highest rate of recurrence [8].

In our cases the oncoplastic techniques allowed for a safe wide excision and there was no recorded recurrence after follow-up of a period of more than for the first six months as this was the time limitation of our study.

These good results are most probably due to the wide field of action that allowed for wide safe excision, and not due to the benign or border line benign nature of the tumors. Moffat et al., investigated the histological features and clinical outcomes of 20 patients and determined that tumor recurrence was determined by the presence of tumors at the margins of excision, rather than the histology [9]

By using round block \& periareolar techniques as a surgical approach, results can be obtained, which provide the requirement for a satisfying cosmetic outcome. These techniques are also a favorable option for surgical treatment of large benign lesions, as described in our cases.

Regarding excision of the multiple lesions; the round block technique gave us a very good accessibility to remove all lesions; the round block technique is known to be the most "forgiving" of all quadrants. It allows for easy accessibility to any lesion in most areas of the breast with a very acceptable fading out scar "scar less excision", while the periareolar technique provides a less accessibility to the lesions in different quadrants, but it has a very excellent cosmetic outcomes so can also be called "scar less excision" [5].

This technique can be used safely in small breasts. Complete surgical excision and tracing all lesions, especially multiple intrapapillary cysts, is not known whether curative or not and a special life-time follow-up is recommended to trace any newly developed lesions or subsequent cancer development [10].

There are some reported cases of mastectomy following recurrences after conventional surgical techniques. Through this combined technique (oncoplastic techniques) we had the widest field of action; we avoided missing of any lesion, we have done our best to remove all lesions, and we avoided mastectomy and unacceptable cosmetic results [11]

We feel that recurrences are due to the narrow field of action that causes difficult delivery of the lesion with incomplete excision of an intact capsule and the presence of the lesion at the surgical margins of resection and might be due to the missing of some inaccessible lesions [11]

A good cosmetic outcome from breast surgery is associated with better psychosocial adjustment after treatment, this psychological adjustment is much more significant in the young unmarried females and should receive more care in this group of women. In benign lesions the acceptance of cosmetic outcome is different from malignant lesions; in malignant lesions patients might be concerned more with the cure from the cancer more than the cosmetic outcome. In benign lesions the patients doesn't have the psychological trauma of cancer; they are usually directed to the cosmetic results and not the cure from the disease.

Indications for oncoplastic techniques in benign lesions although it is very difficult to establish a standard of care since each patient has her own features, and the indications for such an approach were few in the initial years of the oncoplastic techniques. Oncoplastic surgery is thus a useful tool in different benign lesions situations. The results obtained encouraged us to integrate oncoplastic surgery into our surgical protocol every time a standard lumpectomy would not be suitable, where there was the need for a large resection, or where there was a high risk of deformity or where multiple incisions are needed to remove wide apart lesions, or there was a higher risk of recurrence of the lesions.

The choice of technique is an individual process resulting in the interrelationship of certain factors such as tumor size, tumor to breast volume ratio, location(s) of the lesion(s), the pathology of the tumors, the preferences and skill of surgeon and the wishes of the patient.

Planning for oncoplastic breast surgery includes selecting the most effective techniques for parenchymal excision and placing accurate pre-operative markings on the skin. The breast size and the patients' age, general status, and personal potentials are also taken in consideration [12] 
The mean age of our study was 39.2 years, $50 \%$ of the cases fall between 20 to 54 years which is consistent with the demographic data published by National Cancer Institute at 2006 by Greydanus et al., [13] who claimed the peak incidence of benign breast lesions between $20-50$ years old.

In the last two decades, this new form of breast surgery has developed rapidly not only due to the improving scientific background with better clinical studies but also due to the increasing attention given by surgeons to their patient's quality of life.

Increasing numbers of scientific papers and meeting abstracts about oncoplastic techniques demonstrate the importance of and increasing attention given to this technique. The goal of improving a breast lesions patient's quality of life by introducing BCT in the early 90s. Has now finally been achieved by the introduction of oncoplastic techniques [14].

All of our patients had the tumor in lower outer and upper outer aspects of the breast except 2 patients $(10 \%)$ of the patients whom had the tumor in lower inner aspect, as upper outer quadrant is the most common site of benign breast lesions.

In our study only 5 cases (25\%) have had complications, 3 cases got seroma formation, two of them had nipple parathesia, one of the patient with seroma had partial nipple necrosis, and this is similar to what was published by Vinoth [15] which studied the continuous use of suction drain in seroma formation in patients that underwent oncoplastic surgery. Those who had seroma formation were treated with admission, parenteral antibiotics and repeated aspiration, while partial nipple necrosis was treated with admission, parenteral antibiotics and frequent daily dressing with saline and topical antibiotics, topical re-epithelialization ointments and daily dressing until full recovery. The complications were eradicated within 2 to 3 days in two of the three patients and the patients were discharged on oral antibiotics with a more frequent follow-up schedule.

We reported lower results of surgical site infection $(0 \%)$ than reported by Vilar-Compte et al., [16] (18.9\%) and that reported by Olsen et al., [17] $(4.7 \%)$. None of the previously stated complications resulted in disfigurement or ugly scaring. The operative duration of our study was long at first (90 minutes) but with progression of our study and as we build up more experience the operating time was reduced to (55 minutes). But it's worth mentioning that round block technique consumed longer times than that of the circum areolar technique.
One of our last cases had long operative duration as the patient had breast cup size $G$ which required large volume dissection.

Regarding post-operative hospital stay, the majority of our patients were discharged 24 hours post-operative, however patients who had medical comorbidites as ISHD required longer postoperative hospital stay as there was a delay in their ability to move and to perform normal daily activities in addition to their complaint from postoperative pain.

Regarding post-operative pathological outcome, post-operative results provided by our pathologist showed that all of our patients had fibroepithelail stromal tumors of benign nature which match with the recent statistics by breastcancer.org which claims that about $80 \%$ of all benign breast lesions are fibroepithelail stromal tumors.

In our study none of the patients had any recurrence as confirmed by the pathologist in our multidisciplinary team proving that we had performed a safe oncoplastic technique from oncological point of view. The follow-up of the recurrence was for the first six months as this was the time limitation of our study.

The round block technique had the highest mean cosmetic outcome score 4.75 which approaches the excellent score. 9 out of 10 cases of round block technique scored excellent with $90 \%$. The wound being obscured around the NAC at the transitional zone between NAC and skin played an integral role in improving cosmetic outcome, patient satisfaction and acceptance in both early post-operative period and late follow-up period. None of the cases have been given below very good score. This is similar to what was published by Bertozzi et al., [18] who reported that round block technique can be easily performed on tumors in any location; however, it is most suitable for tumors that are close to the areola giving an excellent aesthetic outcome.

Regarding patient satisfaction and quality of life, our patients reported high scores above 90 in all domains which reflect the excellent outcome of the applied oncoplastic techniques in our study. Losken [19] reported that the aesthetic results were good at 1 year $(97.7 \%)$ and at 5 years $(90.3 \%)$ in a series of 540 consecutive cases of patients with high tumor/breast volume ratios. Age, BMI, size and location of the tumor, breast size, and the adjuvant treatment applied can affect the final cosmetic outcome. 
The aesthetic results in the reported study were analyzed by means of patients' self-evaluated questionnaires or subjective scales completed by specialists. It emerged that young patients at high social and economic levels have lower satisfaction rates. Moreover, it appears that patients' evaluations are usually better than those of the specialists. In our study we were able to conduct an excellent cosmetic outcome for a relatively large tumor excisions with $70 \%$ of the cases (14 patients) falling in excellent and very good score groups with mean cosmetic outcome score 4.26. Another 20\% (2 cases) which fall in good and fair score groups as one those two patients noticed asymmetry of the two breasts in front of the mirror. And the other had partial nipple necrosis which required longer period of time in daily dressing and appliance of topical creams till full recovery, none of our cases have had a poor or an ugly score.

Patients are more worried about deformities than a mismatch in the size of their breasts or scar length. Therefore, the aim of OBS is to reshape the remaining breast gland while maintaining an aesthetically pleasant shape and contours. Indeed, contralateral surgeries are often performed to achieve symmetry. OBS esp. round block techniques can also prevent NAC displacement by anticipating possible NAC deviation and repositioning it at the center of the breast mound [18]

Future studies need to further validate the oncological safety of OBS and provide surgeons with adequate pre-operative tools to better plan the resection and reconstructive steps. Although OBS is more complicated and time consuming than the conventional BCT approach and has better oncological outcomes and satisfaction rates, breast surgeons should be also trained in plastic surgery or should at least collaborate with plastic surgeons when performing OBS [18].

\section{Conclusion:}

- The application of oncoplastic surgery to benign breast disease is a new revolution in the surgical management of cases and should be the standard of care for selected cases.

- Oncoplastic techniques can be applied with success in cases with benign breast lesions with favorable cosmetic outcome. It allows for safe wide resections, acceptable scars, less deformity and prevents recurrences in previously reported cases with higher incidence of recurrence and avoids mastectomy and its bad psychological effects. We advocate applying oncoplastic techniques in cases with giant and multiple benign lesions whenever possible.
- The choice of the oncoplastic technique is mainly based upon the location of the tumor, size of the breast and distance of the tumor from the nipple areola complex. So all cases should be adequately reviewed in order to tailor the decisions for every single case.

- Round block techniques and circum areolar techniques proved to have a better cosmetic outcome and accessibility to the tumor and patient satisfaction and less complication than conventional breast surgeries in excision of giant or multiple benign breast lesions.

- Also the round block techniques proved to have a better outcome than the circumareolar technique in all the previous mentioned criteria.

\section{References}

1- KONG X., CHEN X., JIANG L., MA T., HAN B. and YANG Q.: Periareolar incision for the management of benign breast tumors. Oncology letters, 12: 3259-63, 2016.

2- ONSTAD M. and STUCKEY A.: Benign breast disorders. Obstetrics and Gynecology Clinics, 40: 459-73, 2013.

3- BRAMHALL R.J., LEE J., CONCEPCION M., WESTBROEK D., HUF S., MOHAMMED K., THIRUCHELVAM P. and GUI G.P.: Central round block repair of large breast resection defects: Oncologic and aesthetic outcomes. Gland Surgery, Dec., 6 (6): 689, 2017.

4- HALOUA M.H., KREKEL N.M., WINTERS H.A., RIETVELD D.H., MEIJER S., BLOEMERS F.W. and VAN DEN TOL M.P.: A systematic review of oncoplastic breastconserving surgery: Current weaknesses and future prospects. Annals of surgery, 257: 609-20, 2013.

5- NOUR A., GHARIEB F., TASHKANDI M. and HELMY T.: Oncoplastic breast surgery for the management of giant and multiple benign breast lesions. European Surgery, 43: 295-301, 2011.

6- GOLDBLUM J.R., WEISS S.W. and FOLPE A.L.: Enzinger and Weiss's soft tissue tumors E-book, Elsevier Health Sciences, 2013.

7- CHAMPANERIA M.C.: A Complete History of Breast Reconstruction. Breast Reconstruction. Springer, 2016.

8- COWAN M.L., ARGANI P. and CIMINO-MATHEWS A.: Benign and low-grade fibroepithelial neoplasms of the breast have low recurrence rate after positive surgical margins. Modern Pathology, 29: 259-65, 2016.

9- MASTERSON L., ROUHANI M., DONNELLY N.P., TYSOME J.R., PATEL P., JEFFERIES S.J., ROQUES T., SCRASE C., MANNION R. and MACFARLANE R.: Squamous cell carcinoma of the temporal bone: Clinical outcomes from radical surgery and post-operative radiotherapy. Otology \& Neurotology, 35: 501-8, 2014.

10-WEI C.H. and HARARI A.: Parathyroid carcinoma: Update and guidelines for management. Current treatment options in oncology, 13: 11-23, 2012. 
11- BENSON J.R., JATOI I., KEISCH M., ESTEVA F.J., MAKRIS A. and JORDAN V.C.: Early breast cancer. The Lancet, 373: 1463-79, 2009.

12- MASSETTI R. and SLGARELLO C.: Designing the oncoplastic operation. partial breast reconstruction. Quality Medic al Publishing, 203-17, 2009.

13- GREYDANUS D.E., MATYTSINA L. and GAINS M.: Breast disorders in children and adolescents. Primary Care: Clinics in Office Practice, 33: 455-502, 2006.

14- ROUGHTON M.C., SHENAQ D., JASKOWIAK N., PARK J.E. and SONG D.H.: Optimizing delivery of breast conservation therapy: A multidisciplinary approach to oncoplastic surgery. Annals of plastic surgery, Sep. 1; 69 (3): 250-5, 2012.

15- VINOTH R.: A Study on Role of Continuous Suction Drain Tube in Postmastectomy Seroma Collection in Carcinoma Breast. Stanley Medical College, Chennai, 2017.
16- VILAR-COMPTE D., ROSALES S., HERNANDEZMELLO N., MAAFS E. and VOLKOW P.: Surveillance, control, and prevention of surgical site infections in breast cancer surgery: A 5-year experience. American Journal of Infection Control, Oct. 1; 37 (8): 674-9, 2009.

17- OLSEN M.A., NEPPLE J.J., RIEW K.D., LENKE L.G., BRIDWELL K.H., MAYFIELD J. and FRASER V.J. Risk factors for surgical site infection following orthopaedic spinal operations. JBJS, Jan. 1, 90 (1): 62-9, 2008.

18- BERTOZZI N., SIMONACCI F., GRIECO M.P., GRIGNAFFINI E. and RAPOSIO E.: The biological and clinical basis for the use of adipose-derived stem cells in the field of wound healing. Annals of Medicine and Surgery, 20: 41-8, 2017.

19- LOSKEN A., DUGGAL C.S., DESAI K.A., McCULLOUGH M.C., GRUSZYNSKI M.A. and CARLSON G.W.: Time to completion of nipple reconstruction: What factors are involved? Annals of plastic surgery, May 1, 70 (5): 530-2, 2013.

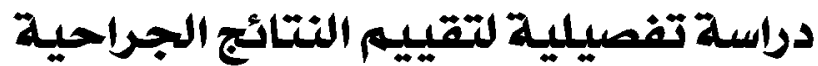

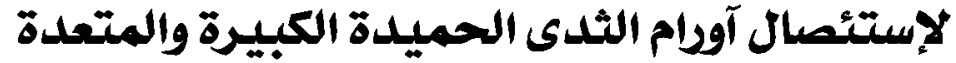

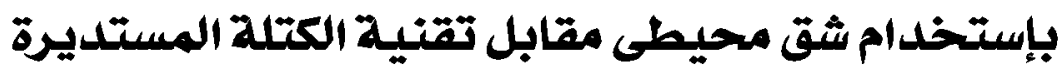

الخلفية: مرض الثدى يؤثَّ بشكل سلبى على الصحة الجسدية والنفسية المرآة. وفى السنوات الآخيرة، تزايدت معدلات الإصابة بآقدام الثى الحميدة والآورام الخبيثة.

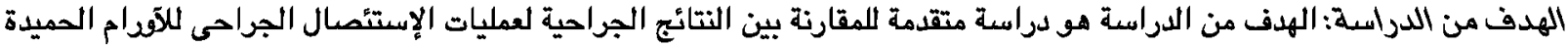

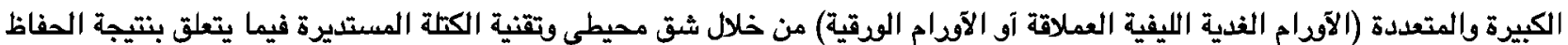

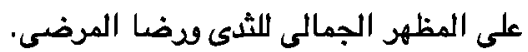

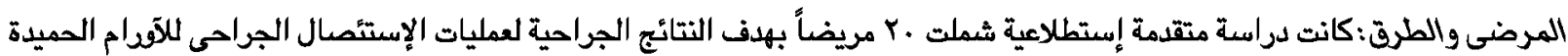

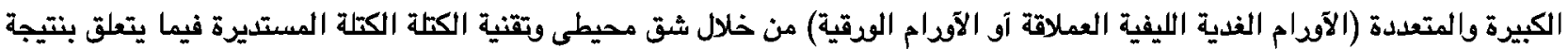

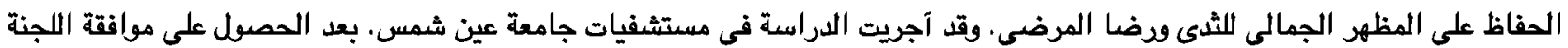

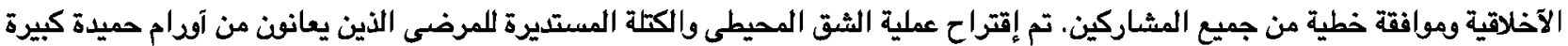

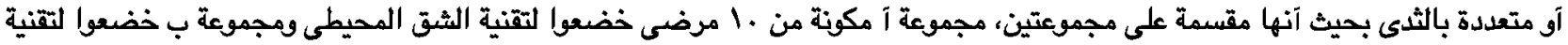

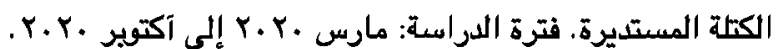

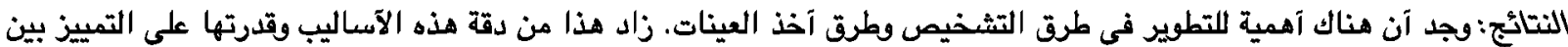

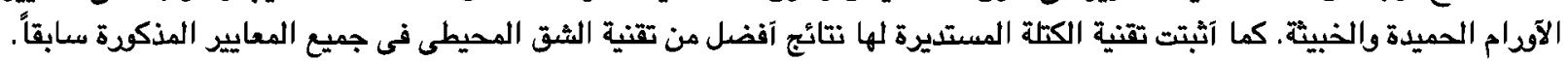

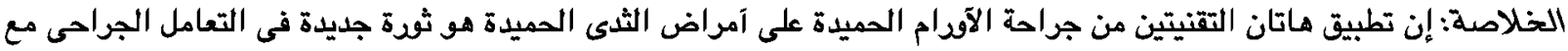
حالات الثىى الحميدة ويفضل آن تكن معيار اللتعامل مع مثل هذه الحالات من الآن الآن فصاعد. 